\title{
AN OLD/NEW VISION OF EUROPE. NATIONAL RESPONSIBILITY AND CULTURAL OTHERNESS IN EMINE SEVGI ÖZDAMAR'S PLAY PERIKIZI
}

\section{Gabriella Pelloni}

University of Verona. Verona, Italy. Email: gabriella.pelloni[at]univr.it

\begin{abstract}
Emine Sevgi Özdamar's play Perikizi (2010) is a particularly significant migration story because of its shrewd exploration of European integration, specifically in Germany. The protagonist is a girl who undertakes an adventurous journey from Turkey to Europe in order to realize her dream of becoming an actress. The play thus delves into the problem of integration in Europe from both the internal and external perspective of a young woman from a country whose culture and history are deeply intertwined with Europe's, but are exotic enough to represent the cultural 'other' in the eyes of every European. I focus on an issue that is a golden thread throughout the play: the connection between genocide, nationalism and xenophobia, a thematic complex told from the perspective of a character who discovers the chance for change on her journey from East to West. I demonstrate that Perikizi's journey highlights some structural parallels between East and West with respect to these issues. The play opens up a space in which national responsibility and the relationship with cultural otherness are problematized through different aesthetic strategies. At the end, it depicts a vision of Europe that is an alternative to a past, and a present, of nationalist and racist crimes.
\end{abstract}

\section{Keywords}

Emine Sevgi Özdamar; Perikizi; Ein Traumspiel; theatre; dream; migration; journey; trauma; genocide; nationalism; integration.

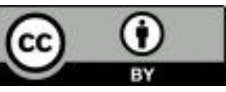

This work is licensed under a Creative Commons «Attribution» 4.0 International License 


\section{СТАРОЕ / НОВОЕ ВИДЕНИЕ ЕВРОПЫ. НАЦИОНАЛЬНАЯ ОТВЕТСТВЕННОСТЬ И КУЛЬТУРНАЯ ИНАКОВОСТЬ В ПЬЕСЕ ЭМИНЕ СЕВДЖИ ОЗДАМАР «ПЕРИКИЗИ» («МАЛЕНЬКАЯ ФЕЯ»)}

Пеллони Габриэлла

Веронский университет. Верона, Италия. Email: gabriella.pelloni[at]univr.it

\section{Аннотация}

Пьеса Эмине Севджи Оздамар “Perikizi” («Маленькая фея»), (2010) является необычайно важным рассказом о миграции благодаря проницательному исследованию европейской интеграции, особенно в Германии. Главный герой - девушка, которая отправляется в авантюрное путешествие из Турции в Европу, чтобы осуществить свою мечту стать актрисой. Таким образом, в пьесе рассматривается проблема интеграции в Европе как с внутренней, так и с внешней точки зрения молодой женщины из страны, чья культура и история глубоко переплетаются с европейскими, но достаточно экзотичны, чтобы представлять культурного «другого» в глазах каждого европейца. Статья сосредоточивается на проблеме, которая служит золотой нитью на протяжении всей пьесы: это связь между геноцидом, национализмом и ксенофобией, тематический комплекс, рассказанный с точки зрения персонажа, который обнаруживает возможность перемен в своем путешествии с Востока на Запад. Показано, что путешествие Перикизи демонстрирует некоторые структурные параллели между Востоком и Западом по отношению к этим вопросам. Пьеса раскрывает пространство, в котором национальная ответственность и отношения с культурной инаковостью проблематизируются с помощью различных эстетических стратегий. В конце она изображает видение Европы, которое является альтернативой прошлому, и настоящее националистических и расистских преступлений.

\section{Ключевые слова}

Эмине Севджи Оздамар; Перикизи [Маленькая фея]; Ein Traumspiel [мечта, игра грез]; театр; мечта; миграция; путешествие; травма; геноцид; национализм; интеграция

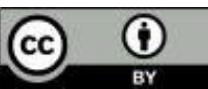

Это произведение доступно по лицензии Creative Commons «Attribution» («Атрибуция») 4.0 Всемирная 


\section{INTRODUCTION}

Turkish-born writer Emine Sevgi Özdamar has returned to theatre with her 2010 play Perikizi after many years of writing fiction. The play is adapted from her most significant work of fiction (Özdamar, 2006): her autobiographical trilogy Das Leben ist eine Karawanserei, hat zwei Türen, aus einer kam ich rein, aus der anderen ging ich raus (1990), Die Brücke vom Goldenen Horn (1998), and Seltsame Sterne starren zur Erde (2004). The play's main character, Perikizi, is a girl who undertakes an adventurous journey from Turkey to Europe in order to realise her dream of becoming an actress. Perikizi has a marked intertextual character, which refers not only to the European literary tradition, but also reworks the biographical material that portrayed the female ego in the novels. However, what makes Perikizi a particularly significant migration story is its shrewd exploration of European integration, specifically in Germany, from both the internal and external perspective of a young woman from a country whose culture and history are deeply intertwined with Europe's, but are exotic enough to represent the cultural 'other' in the eyes of every European. In this article, I will focus on an issue that is a golden thread throughout the play: the connection between genocide, nationalism and xenophobia, a thematic complex told from the perspective of a character who discovers the chance for change on her journey from East to West. I will attempt to demonstrate that Perikizi's journey highlights some structural parallels between East and West on these issues. At the same time, it opens up a space in which national responsibility and the relationship with cultural otherness are problematised through different aesthetic strategies, in order, finally, to depict a vision of Europe that is an alternative to a past, and a present, of nationalist and racist crimes.

\section{I}

Özdamar wrote Perikizi for "Odyssee Europa", a theatre festival sponsored by the main theatres of the Ruhr cities in 2010. Six German-speaking playwrights were asked to rewrite the myth of Odysseus in the present day as a modern interrogation of European identity. ${ }^{1}$ In Perikizi, Odysseus is portrayed as a young Turkish woman, a radical departure from the modern rewritings of The Odyssey (Schlößler, 2010, pp. 79-95). Odysseus' patriarchal myth, an archetype of a quest for knowledge linked to trial and pain, is thus transformed into the story of a young woman's migration, a station drama that sees her leaving Turkey, crossing the war-torn places of the former Yugoslavia, landing in a burnt-out German forest, then descending into

1 The six plays are published in Carstensen/von Lieven (2011). 
the Underworld to finally return to her native Istanbul. As evoked by the subtitle, Ein Traumspiel (“A Dream"), Perikizi's journey has clear oneiric traits (Höfer, 2019, p. 127-173), which make it first and foremost a metaphor for a psychic act. In its both real and mythical dimension, the journey is configured as a process of transformation, in which confronting the traumas of the past assumes a central role. ${ }^{1}$

The play opens with a long scene that evokes recent Turkish history through the experiences of Perikizi's family members. The link between Turkish and German history ${ }^{2}$ emerges for the first time when Perikizi's grandmother recalls the alliance between the two countries in the First World War and the genocide of the Armenians and other minorities by the Ottoman Empire. Perikizi's grandmother lost her husband and seven children in the war; she is still haunted by the ghosts of the past and by the violence she witnessed as a young girl, particularly her traumatic memory of the Armenian genocide. The trauma, evoked by a single word, is expressed in physical reactions, such as her nose bleeding when she speaks. She also voices her experience of violence with a repetitive litany reminiscent of a death march during which two young Armenian women from her village died:

\begin{abstract}
Abooo, Aboooo. ${ }^{3}$ Wie die armenischen Bräute sich von den Brücken heruntergestürzt haben. Wie die armenischen Bräute sich von den Brücken heruntergestürzt haben. Gesehen haben sie mit ihren jungen Augen, die blind sein wollten, die Hölle und das Feuer auf dieser Erde, die Schürze noch über ihren Kleidern, barfuß, die Augen groß, die Hände groß, die Füße groß vom Totenmarsch, ihre Kinder als Skelette vor ihren Füßen, das Feuer, in dem sie lange liefen, liefen und liefen, war siebenmal heißer als das Höllenfeuer. [...] Wir waren gute Nachbarn dieser Bräute. Als sie noch lebten, kamen armenische Zeitungen aus Istanbul ins Dorf. Als sie starben, kamen keine Zeitungen mehr. Wohin sind all diese Menschen gegangen, wohin? ${ }^{74}$ (Özdamar 2011, pp. 275-276)
\end{abstract}

The grandmother's nightmares also torment her granddaughter, who at times takes on her ductus and voice, reporting the events of the genocide in a sort of unconscious re-emergence of the trauma, which extends

1 On the phenomenon of transnational identity building in Özdamar's fiction see recently Genz (2016, pp. 91-114).

2 The theme of the connection between German and Turkish history is dear to Özdamar, as it is told also in the novel Seltsame Sterne starren zur Erde (Konuk, 2010, pp. 221-242).

3 "Aboo" is a Turkish colloquial exclamation indicating great astonishment, consternation and despair.

4 "How the Armenian brides threw themselves off the bridges. How the Armenian brides threw themselves off the bridges. They saw hell and fire on this earth with their young eyes that longed to be blind; their aprons still over their clothes, barefoot, their eyes bulging, their hands and feet swollen from the death march, their children, skeletons at their feet, the fire they walked through on their endless march burned seven times fiercer than the fires of hell. [...] We were good neighbours to these brides. When they were alive, Armenian newspapers came to our village from Istanbul. When they died, no more newspapers came. Where did all these people go, where?" (Author's translation, like all those from Özdamar). 
at an unconscious level from one generation to the next. Once awake and conscious, Perikizi dismisses her grandmother's memories, which are steeped in a violence that has never been processed. Her desire to emigrate to Europe arises firstly from this suffering, and secondly from the need to seek alternative possibilities of existence and new models of identification. Perikizi's passion for theatre is also an expression of this quest. When the play opens, she has a copy of A Midsummer Night's Dream under her arm and reads the role of Titania, the fairy queen, who enchants with her voice and words. Perikizi means "daughter of the fairies" in Turkish. When she was a child, her mother shut her in a tomb to cure her of an illness, an event that emphasises her liminal existence. Perikizi is suspended between life and death, reality and dreams, past and future, between the world of her childhood (Turkey), and the destination of her journey (Europe).

In the second part of the scene, Perikizi's parents take the stage. Their opening words make it clear that the events of the war, their own parents' death, and the subsequent historical developments in Turkey embody a central part of their generation's identity, as well. Her parents are also scarred by the trauma of a great loss that resurfaces in their harsh reaction to Perikizi's desire to emigrate to Europe: "Sie werden goldene Sterne auf dein Haupt schütten, wohlan zu dieser Europa. Die Toten, die sind unsere Götter, nie werden sie dir verziehen, du Ruhelose." ${ }^{1}$ (2011, p. 285). The mother's words reflect the tendency to shift the blame for the war onto others and to completely exonerate their own country of any guilt. Her parents' arguments, full of prejudice and racist clichés, are a clear example of the nationalistic rhetoric of blood and soil (Blut und Boden) that still exists in Turkey today. As part of these arguments, Perikizi's father warns of the loneliness, alienation and discrimination that await her in Europe. He uses the example of Odysseus, who calls himself "Nobody" to escape from the Cyclops' lair:

Meine schöne Tochter, Odysseus hatte gesagt, er hieße Niemand. Das rettete ihn, aber im Vergleich zum geistigen Riesenformat des Kyklopen ist er tatsächlich ein Nichts, ein Niemand. Der Kyklop ist ein Riese, weil sein Bewusstsein riesige Gebiete umfasst. Der Riese lebt in seiner Umgebung, hat Schafe, Lämmer und Ziegen, das ist sein Land. Odysseus ist aber auf seiner Irrfahrt in der Fremde beinahe zu einem Nichts, Niemand geschrumpft. [...] Ein Niemand besitzt am Ende nur Einsamkeit des Ichs, in dem Leiden, leere Hoffnungen, Verluste, wie vom Licht geblendete Fledermäuse zu Hause sind. ${ }^{2}$ (2011, p. 287)

1 "They will pour golden stars onto your head. Go to this Europe, then. The dead are our gods; they will never forgive you, you restless girl."

2 "My beautiful daughter, Odysseus said his name was 'Nobody'. This saved him, but compared to the enormous Cyclops, he is nothing: a nobody. The Cyclops is a giant because his consciousness covers vast areas. The giant lives in his own land; he has sheep, lambs and goats, that is his land. Odysseus, however, on his voyage abroad, shrunk to almost nothing, nobody. [...] In the end, all a nobody possesses is his own loneliness. Within it, he knows only suffering, empty hopes, loss, like bats 
Perikizi's father fears that his daughter risks losing her individuality, with her being reduced to a stereotype and forced to occupy a subordinate position in society:

Nehmen wir an, du schreibst einen Roman, mit all deinen Phantasien, deinen empfindsamen Gefühlen [...] Diese Schöpfungen, die du aus deinem eigenen Körper ausgraben wirst, werden unter Türkisch registriert. Sie werden sagen: "Schauen Sie, wie schön die türkische Sprache ist." Keiner kann Türkisch, aber plötzlich wissen sie, dass es Türkisch ist.

Du landest in der türkischen Schublade. Europa, Tiergarten der Sprachen, hier sind die türkischen Tiere. Als wäre die Türkei ein Dorf, in dem alle Einwohner die gleiche Erfahrung haben. So werden sie versuchen, dir dein Gedächtnis auszulöschen, weil sie keines haben. Weil sie keines haben, darfst du auch keines haben. ${ }^{1}$ (2011, pp. 291-292).

On the one hand, he insists that identity is individual research and work, thus undermining the idea of a homogeneous, exclusive nationality; on the other hand, he clings to his belief in a "true" Turkish identity constructed through a rigid, clear-cut dichotomy between the "self" and the "other". His beliefs include denigrating Turkish migrants, who are guilty, in his view, of creating a reductive and pejorative image of Turkey in Europe:

Wir sind hier modern, wir haben unsere Geschichte, unsere Reichtümer, unsere Kultur. Die, die weggegangen sind, sind die Armen, die Kulturlosen, die Sklaven. Durch sie wird in Europa unsere wahre Identität, unsere reiche Geschichte klein gemacht. Plötzlich schrieb Europa unsere reduzierte Geschichte. Ridicule. ${ }^{2}$ (2011, p. 288)

Perikizi's father is therefore the spokesman for an identity discourse founded upon the belief that the mixing of cultures is potentially dangerous and destined only to produce violence:

Die armen europäischen Leute, die werden mir alle leidtun, ob sie lächeln, oder böse schauen. Ausländer machen die Einheimischen zu Pförtnern. Die Fremden werden das Land, in dem sie ankommen, immer zweiteilen. Das bedeutet Wörterkrieg unter den zweigeteilten Einheimischen. Überleg dir nur einen Moment lang, dass du die

blinded by the light."

1 "Let's say you write a novel, with all your dreams, your feelings [...] The works you prise from your own body will be recorded as Turkish. They will say: 'Look how beautiful the Turkish language is.' Nobody knows Turkish, but suddenly everyone understands it. You end up in the Turkish drawer. Europe, zoo of languages; here are the Turkish animals. As if Turkey were a village where all its inhabitants have the same experience. They will try to erase your memory because they don't have one. Because they don't have one, you can't have one either.'

2 "We are modern here, we have our history, our resources, our culture. The emigrants are the poor, the cultureless, the slaves. They shrivel our true identity, our rich history and serve it up to Europe. All of a sudden, Europe has penned a brief history of Turkey. Ridiculous." 
Menschen, die dort geboren sind, täglich zwingst, zum Pförtner zu werden. ${ }^{1}$ (2011, p. 288)

During Perikizi's journey, her father's vision of individual identity is taken to extremes by characters she meets along the way; these extremes, however, are mocked and ridiculed at the same time. The setting of the opening scene, the city of Istanbul, is immediately connoted as a place of cultural contamination. This connotation is almost satirising her father's words. Two musicians, one Greek and one Turkish, then appear on the scene singing traditional Greek, Turkish and Armenian songs, as if to recall and celebrate the multi-ethnic and multi-cultural roots of modern Turkey. The relevance of this scene thus lies in its reminding the audience that Turkey's multi-cultural history has been removed. Perikizi's response to her father's words "Vater, ich mache die Geschichte wieder groß" (2011, p. 288) can be therefore be interpreted as ironic.

On the one hand, the journey depicted in the subsequent scenes becomes an opportunity to tackle the nationalistic discourses conducted in Europe, both among native Europeans and migrants; on the other, it sheds light upon the deep connection between the past of two countries. Turkey is stained with guilt that has been erased from the collective memory, and Germany continues to struggle with the ghosts of its past. Along her journey, Perikizi is accompanied by the shadows of the representatives of the war: a young soldier - her deceased grandfather - followed by a donkey, and the two young Armenian women who died on the march. Perikizi is endowed with an uncommon sensitivity, as she interacts with the dead and becomes their spokesperson, thus reaffirming the liminal nature of her existence. This theme is dear to Özdamar, as in her first novel, Das Leben ist eine Karawanserei, she describes the intimate bond between granddaughter and grandmother, the slender thread that united Perikizi's existence with that of the dead. During a later scene, entitled "Perikizi's Dream" (Perikizis Traum), the two Armenian women are given a voice for the first time, but they can only hint indirectly at the violence they suffered: "Wir dürfen nicht. Wir dürfen nicht sprechen. / Schon ewig lange dürfen wir nicht sprechen." ${ }^{3}$ (2011, p. 312). Significantly, the death march on which the two young women died is told by the moaning of two fig trees that watched them pass. This strategy represents the extent to which Turkey has removed the genocide from its history, with the scene concealing a pregnant allusion to current

1 "Poor Europeans, I feel sorry for them all, whether they smile, or frown. Foreigners turn the natives into gatekeepers. Foreigners will always split their destination country in two. This means word warfare among the divided natives. Just think: you are forcing the people who were born there to act as gatekeepers every single day of their lives."

2 "Father, I am going to restore history to greatness once more."

3 "We have been silenced. We have been silenced. / We have been silenced for so long." 


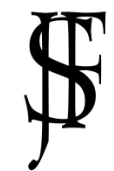

Журнал Фронтирных Исследований. 2021. No 2 | ISSN: 2500-0225

Пограничные исследования в современной европейской литературе | Doi: https://doi.org/10.46539/jfs.v6i2.299

events, i.e. the Turkish government's refusal to recognise the genocide, and thus to the possible risks that talking openly about it may have. However, the dream also plays an important part in helping Perikizi to mature (Jonczyk, 2015, pp. 117-132), as afterwards she accepts the reality of the past, i.e. the deads' testimony of the horrors of war and genocide. Therefore, Perikizi contrasts the collective removal of the historical traumas of her native country and its current nationalistic and xenophobic tendencies, gaining a new awareness of the past by searching for alternative possibilities for the present in her Fremde, ${ }^{1}$ her migration.

\title{
II
}

During her journey, Perikizi encounters two central features of European identity: the tendency to exclude otherness, which originates from the perception of identity as something homogeneous and static; and the bureaucratic regulation of migratory flows. On the train through the former Yugoslavia, three prostitutes tell Perikizi that in Europe she will be reduced to a passport and a stay-and-work permit, words that suggest her father's warning is about to come true. Indeed, Perikizi remains invisible to most people, as we can observe it in the scene "In the half-burnt forest" (Im halb verbrannten Wald). The forest is reminiscent of the setting of A Midsummer Night's Dream, a mythical place in a fantasy world, but one that is scarred by the devastation of war. Moreover, the forest is also one of the most significant symbols of German culture, with its destruction symbolising a nation still deeply troubled by the crimes of its past. The burnt-out forest is the setting for a meeting between Perikizi and the spokesmen for discourse on the Holocaust and Nazism. These spokesmen are three one-eyed giants, an image that recalls the Cyclops in The Odyssey mentioned by Perikizi's father. Significantly, they are referred to as "guilt giants", and portrayed as red-faced intellectuals who swallow sausages, drink, and even wash themselves in beer. They speak in unison and drill holes in their heads to drive out traumatic memories, thus deleting them. Their choral speech on Nazism and the Holocaust resembles a funeral song and is nothing but empty phrases and platitudes:

\author{
SCHULDGEFÜHLECHOR \\ Wir sind die Schuldgefühle des Kriegs. \\ Wir hassen unsern Vater, \\ unsere Mutter, gesündigt haben \\ sie, gesündigt. Wir leben hier in Sünde. \\ Die Sünde ist groß, viel zu groß, \\ unsre Geschichte ein bittres Los.
}

1 On the concept of "Fremde" in Özdamar's work see Perrone Capano (2007a, pp. 109-147), (2007b, pp. 245-260). 
Unser Wald ist verbrannt, nicht zu retten,

von bösen Vaterfüßen zertreten.

Unsere Köpfe sind leer;

von tausend Fragen schwer.

Was geschah in unserem Wald? ${ }^{1}$

(Özdamar 2011, pp. 301-302)

This scene, which can be read as an adaptation of the episode of Odysseus and the Cyclops in The Odyssey, has two meanings: first, selfaggression and sterile fixation on collective guilt are the main ways in which Germany has dealt with its past crimes; second, the giants' pathological concentration on themselves and their obsession with guilt and pain make them blind to the point that they do not even notice the migrant, thus producing a new form of exclusion and violence.

The following scene takes place in a guesthouse for female workers (Gastarbeiterinnen) in Germany. This is a key-place in Özdamar's both real and symbolic topography. In the novel Die Brücke vom Goldenen Horn, the protagonist left Turkey for Berlin in the mid-1960s, finding a new community of belonging among the girls living at the guesthouse. In the play, however, the guesthouse is where Perikizi first comes into contact with Turkish ultra-nationalism. One of the three Turkish workers appears on stage in a chicken costume and waves a Turkish flag, asking Perikizi aggressively if she is an ethnic Armenian. The girl also wears a bandage over a bleeding eye, another reference to the Cyclops, but also, most significantly, to the three guilt-giants. Through the motif of the blinded eye, Özdamar establishes a connection between current Turkish nationalism and the similarly blind and violent self-hatred of the representatives of Holocaust discourse in Germany. This connection is further developed by a later scene entitled Die Sprachlosigkeit im halb verbrannten Wald ("Speechless in the half-burnt forest"). A wolf, dressed as an intellectual, clearly representing the Turkish nationalist movement the Grey Wolves, puts on an anti-German show, as he makes obscene and provocative gestures at the giants: "Meine lieben abendländischen vernünftigen Freunde, ich bin gegen die Aufklärung. Ihr seid traditionsbewusst, wauwauwauwau, unser gemeinsamer Kampf geht weiter, Freiheit für viele Moscheen, aber mit Minarett, bitteschön, wauwauwau. Freiheit für Schamtücher der Frauen, wauwauwauwau." (2011, p. 329) This scene shows how a dogmatic, pseudo-intellectual confronting of the past both

1 "GUILT CHOIR: We are the guilt of war. / We hate our fathers / our mothers, they sinned, / sinned. Sin is all around us, here. / Sin runs deep, far too deep, / Our history has a bitter fate. / Our forest is burnt, no one can save it, / trampled underfoot by wicked fathers. / Our heads are empty, but / burdened with a thousand/ questions. What happened in our forest?"

2 "My dear reasonable Western friends, I am against enlightenment. You are tradition-conscious, woof woof, our common struggle continues, freedom to build hundreds of mosques, but with minarets, here you go, woof woof. Freedom for women to wear veils, woof woof woof." 
obstructs an equal relationship between migrants and non-migrants, and provides fertile ground for the emergence and growth of extremist positions and radical exclusionary attitudes on both sides, as the only means it has of combatting the ideology of racial superiority is collective self-aggression and self-humiliation.

Perikizi's experience in a foreign land thus sheds light on the intrinsic dynamics governing relations between migrants and non-migrants in Germany. She is often reduced to clichés and stereotypes, with this being particularly evident when two German girls ask her questions that she does not understand and can only answer in monosyllables. The girls' questions reveal all of the stereotypes Germans have about migrants, such as whether Perikizi wears a veil. ${ }^{1}$ Yet, she also experiences discrimination in the shape of aggressive and violent Turkish nationalism, ${ }^{2}$ which prospers in Germany because of the unhealthy relationship Germans have with historical collective guilt and, as a consequence, with cultural otherness. Significantly, the guiltgiants refuse to help Perikizi and even take the wolf's side when he binds a veil around her head, saying: "DIE DREI SCHULDGEFÜHLE-GIGANTEN: Steh doch, steh doch zu deiner wahren Identität. Keine Angst vor uns Abendländern. Keine Angst vor uns Abendländern.”3 (2011, p. 330)

In the final scenes, however, it becomes clear that Perikizi's journey has not been in vain despite the humiliation she has suffered. During her migration journey, she learns to deal with her grandmother's trauma, embracing her perspective and allowing memories to emerge and become part of her own identity. In the conciliatory scene that takes place in the Underworld (Im Hades), which is interspersed with verses from Hölderlin's Hyperion, the two Armenian women and Perikizi's grandfather appear alongside with Hölderlin himself. The encounter between Perikizi and the dead women represents a past experience being handed down from generation to generation; it is wisdom that cannot be silenced and benefits both parties as it enables them to process what happened: "SOLDAT: Wenn Du nicht weiß, wie es weitergeht, musst du zu den Toten zurückkehren, mit uns sprechen. So leben wir auch in dir weiter. [...] Nicht nur du lernst von den Toten, die Toten lernen auch von dir." 4 (2011, p. 332)

The episode ends with a verse from Constantine Cavafy's poem Ithaca, which celebrates being on a journey and the experiences had along the way

1 Özdamar's works deconstruct binary oppositions and envision an alternate third space that allows to break out of the confines of organized religion (Murti, 2012, pp. 41-100).

2 On the theme of violence in Özdamar works see Weber (2013, pp. 173-198).

3 “THE THREE GUILTY GIANTS: Stand up, stand up for your true identity. Don't be afraid of us Westerners. Don't be afraid of us Westerners."

4 "SOLDIER: If you don't know how it goes on, you must return to the dead. Speak to us. This way we live on in you. [...] Not only do you learn from the dead, but the dead learn from you." 
rather than the desire to reach the destination quickly: "Ithaka hat dir eine schöne Reise beschert. / Ohne Ithaka wärest du nicht aufgebrochen. / Jetzt hat es dir nichts mehr zu geben". ${ }^{2}$ The scene clearly refers to current developments in Turkish society, but also functions as a warning, since it points to the need to discuss what has been at long last.

The final scene of the play, however, reconnects with the first, as it shows Perikizi sitting in front of a mirror and reciting Titania's words. It is a rejection of the harmonious conclusion suggested in the conciliatory scene in the Underworld, restoring it to nothing but a utopia. By almost entirely reproducing the opening, the final scene removes any teleological purpose from the dramatic action. More realistically, it makes the spectator aware once and for all that it is impossible to come to terms with the past, especially when nationalism and racism are integral parts of a country's history and identity.

\section{CONCLUSION}

Like Özdamar's other plays, the hallmark of Perikizi is its surreal, grotesque style. On the one hand, this style takes its cue from Brechtian estrangement (Gezen, 2018, pp. 77-103); on the other, its mixture of the grotesque, fantastic and carnivalesque is inspired by Bachtin's carnival aesthetics (Mecklenburg, 2007, pp. 85-102). Perikizi wears a donkey mask that she repeatedly takes off and puts on, often referring to herself as a "Schelm" or a "Narr" (i.e. a rascal or a fool); many of the on-stage characters have the appearance of animals; and bodies are often shown naked performing the most basic human functions. However, these carnivalesque elements are only predominant on Perikizi's journey to Europe in the second part of the play, whereas the first long scene in Istanbul is mostly realistic, with the characters' traumatic experiences retaining a tragic aura. Özdamar succeeds in re-establishing history's tragic nature by recounting the unspeakable trauma of the Armenian genocide from the victims' perspective. The function of Perikizi's grandmother and the two Armenian women is to give voice to a past, discussion of which is still forbidden in Turkey. In the second part of the play they act as a tragic counterbalance to German society, whose stereotypes and clichés are ridiculed. ${ }^{3}$ This demonstrates that the two nations take a contrasting approach towards their relationship with the past. The representatives of Holocaust discourse and collective guilt in Germany are grotesque, ridiculous figures, while the Armenian genocide has a painful on-stage presence, as it mourns its victims. The different aesthetic representation of

1 On the theme of impossible return, with reference to the experience of migration and Odysseus as its archetype, cf. Brunner (2004, pp. 71-90).

2 "Ithaka gave you the marvelous journey. / Without her you would not have set out. / She has nothing left to give you now." (Cavafy, 1992, pp. 34-35).

3 On humour and interculturality in Özdamar's work see Mecklenburg (2008, pp. 506-535). 


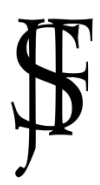

a similar historical event is indicative of how this event is perceived in the respective countries: Turkish society keeps silent about it, but German society talks about it too much, thus draining the discourse of all meaning. Perikizi's journey symbolises the dangerous consequences resulting from both attitudes: the emergence of fresh nationalist and extremist positions in Turkey and an uneasy relationship with cultural otherness in Germany. Perikizi's naive yet sensitive gaze - the gaze of someone who, as her deceased grandfather says, "has a heart" - succeeds in displaying these issues in all their current urgency.

Critics have pointed out that the play's intertextual variety clearly responds to an intercultural strategy of hybridisation (Schlößler, 2010, pp. 7995). This strategy is intended to create a plurality of voices, implying a rejection of the high register in The Odyssey, and thus of ancient Greek culture, which was the first to produce a clear cultural dichotomy between West and East, centre and periphery. This intertextual strategy evidently contains a critique of the use of myth as a factor of continuity / a direct link from the Greeks to the Europeans, and consequently of a vision that excludes 'barbarians' from the path of civilisation. It is no coincidence that one of the poets quoted in the play is Constantine Cavafy; significantly, Ithaca is not the only one of his poems quoted, as the play also features verses from Waiting for the Barbarians, which presents the arrival of the 'barbarians' as the solution to the inertia of the present.

\author{
"Worauf warten wir, versammelt auf dem Marktplatz? \\ Auf die Barbaren, die heute kommen. \\ Warum solche Untätigkeit im Senat? \\ Warum sitzen die Senatoren da, ohne Gesetze zu machen? \\ [...] \\ Warum jetzt plötzlich diese Unruhe und Verwirrung? \\ (Wie ernst die Gesichter geworden sind.) Warum leeren \\ Sich die Straßen und Plätze so schnell, und \\ Warum gehen alle so nachdenklich nach Hause? \\ Weil die Nacht gekommen ist und die Barbaren doch nicht \\ Erschienen sind. \\ Und nun, was sollen wir ohne Barbaren tun? \\ Diese Menschen waren immerhin eine Lösung. " \\ (Özdamar 2011, 326)
}

1 "What are we waiting for, assembled in the forum? / The barbarians are due here today. / Why isn't anything going on in the senate? / Why are the senators sitting there without legislating? / [...] Why this sudden bewilderment, this confusion? / (How serious people's faces have become.) / Why are the streets and squares emptying so rapidly, / everyone going home lost in thought? / Because night has fallen, and the barbarians haven't come. / And some of our men just in from the border say / there are no barbarians any longer. / Now what's going to happen to us without barbarians? / Those people were a kind of solution." (Cavafy 1992, pp. 18-19) 
Perikizi's experience makes it clear that confronting the past lays the foundations for the construction of individual and collective identity. It should make people rethink the crimes of their predecessors so that the negative parts of their legacy can be cast off and new one can be sought. The reference to Cavafy's poems both contrasts with the discourses Perikizi hears in Germany and reveals that Özdamar's proposed connection to the past departs from a vision of Europe characterised by hierarchical and centralised structures, replacing it with one of Europe as thousands of nonlinear paths moving in all directions, just like the people who embarked on 20th and 21st century migrations and diasporas. Her aim is thus to revive an understanding of Europe's mixed and multiple origins and of the connections between cultures.

\section{References}

Allocca, D. (2016). BerlinoGrafie, letteratura nomade e spazi urbani: I percorsi di Emine Sevgi Özdamar e Terézia Mora [BerlinGraphies, nomadic literature and urban spaces: The paths of Emine Sevgi Özdamar and Terézia Mora]. Milano: LED. (In Italian).

Brunner, M. E. (2004). Migration ist eine Hinreise. Es gibt kein „Zuhause”, zu dem man zurück kann [Migration is a journey there. There is no 'home' to return to]. In M. Durzak (Ed.), Die andere deutsche Literatur [The other German literature] (pp. 71-90). Würzburg: Königshausen \& Neumann. (In German).

Budde, J. (2017). Nomadic Narrative: Interkulturelle Stadtnomadinnen. Inszenierungen weiblicher Flanerie- und Migrationserfahrung in der deutsch-türkischen und türkischen Gegenwartsliteratur am Beispiel von Aysel Özakin, Emine Sevgi Özdamar und Asli Erdogan. Studien zur deutsch-türkischen Literatur und Kultur [Nomadic Narrative: Intercultural Urban Nomads. Stagings of Female Flanerie and Migration Experiences in German-Turkish and Turkish Contemporary Literature Using the Example of Aysel Özakin, Emine Sevgi Özdamar and Asli Erdogan. Studies on German-Turkish Literature and Culture]. Würzburg: Königshausen \& Neumann. (In German).

Carstensen, U. B., \& Lieven, S. v (Eds.). (2011). Theater Theater - Odyssee Europa. Aktuelle Stücke 20/10 [Theatre Theatre-Odyssey Europe. Current plays 20/10]. Frankfurt a. M.: Fischer. (In German).

Cavafy, C. P. (1992a). Ithaka. In E. Keeley \& P. Sherrard (Trans.), Collected Poems (Revised Edition, pp. 34-35; By C. P. Cavafy). Princeton University Press.

Cavafy, C. P. (1992b). Waiting for the Barbarians. In E. Keeley \& P. Sherrard (Trans.), Collected Poems (Revised Edition, pp. 18-19; By C. P. Cavafy). Princeton University Press.

Fischer, A. (2014). "Brecht hätte gerne eine Mitarbeiterin wie dich gehabt”. Zur Inszenierung von transkultureller Autorschaft und auktorialem Traditionsverhalten bei Emine Sevgi Özdamar ["Brecht would have liked to have had a collaborator like you". On the Staging of Transcultural Authorship and Authorial Traditional Behaviour in Em- 
ine Sevgi Özdamar.]. In S. Kyora (Ed.), Subjektform Autor: Autorschaftsinszenierungen als Praktiken der Subjektivierung [Subject form author: Stagings of authorship as practices of subjectification] (pp. 247-265). Bielefeld: Transcript. (In German).

Genz, J. (2016). Von der Polyglossie zur Polyphonie - transnationale Identitätsbildung bei Emine Sevgi Özdamar und Roger Manderscheid [From Polyglossia to Polyphony Transnational Identity Formation in the Works of Emine Sevgi Özdamar and Roger Manderscheid]. In N. Potysch \& M. Bauer (Eds.), Deutungsspielräume: Mehrdeutigkeit als kulturelles Phänomen [Interpretive scope: Ambiguity as a cultural phenomenon] (pp. 91-114). Frankfurt a. M: Peter Lang. (In German).

Gezen, E. (2018). Brecht, Turkish theater, and Turkish-German literature: Reception, adaptation, and innovation after 1960. Rochester, New York: Camden House.

Gutjahr, O. (2016). Inszenierungen eines Rollen-Ich. Emine Sevgi Özdamars theatrales Erzählverfahren [Stagings of a Role-It. Emine Sevgi Özdamar's theatrical narrative process]. In Y. Dayioğlu-Yücel \& O. Gutjahr (Eds.), Text + Kritik. Heft 211: Emine Sevgi Özdamar [Text + Criticism. Issue 211: Emine Sevgi Özdamar] (pp. 8-18). München: Richard Boorberg Verlag. (In German).

Höfer, K. (2019). Gespielte Träume und Traumspiele. Traumdarstellungen in der Dramatik des 20. Und 21. Fahrhunderts [Played Dreams and Dream Games. Representations of Dreams in 20th and 21st Century Drama]. München: Fink. (In German).

Jonczyk, A. (2015). Die Identitätssuche im Emine Sevgi Özdamars Roman "Die Brücke vom Goldenen Horn" und im Theaterstück "Perikizi. Ein Traumspiel" [The search for identity in Emine Sevgi Özdamar's novel 'The Bridge of the Golden Horn' and in the play "Perikizi. A Dream Play]. In C. Gansel, M. Joch, \& M. Wolting (Eds.), Zwischen Erinnerung und Fremdheit: Entwicklungen in der deutschen und polnischen Literatur nach 1989 [Between Memory and Foreignness: Developments in German and Polish Literature after 1989] (pp. 117-132). Göttingen: V\&R Unipress. (In German).

Konuk, K. (2010). Taking on German and Turkish History: Emine Sevgi Özdamar's Seltsame Sterne. In A. Neuwirth (Ed.), Europa im Nahen Osten - der Nahe Osten in Europa [Europe in the Middle East-The Middle East in Europe] (pp. 221-242). Berlin: Akademie Verlag. (In German).

Mecklenburg, N. (2007). Karnevalistische Ästhetik des Widerstands. Formen des gesellschaftlich-komischen bei Emine Sevgi Özdamar. Peter-Weiss-Jahrbuch für Literatur, Kunst und Politik im 20. Und 21. Peter-Weiss-fahrbuch für Literatur, Kunst und Politik im 20. und 21. Fahrhundert, 16, 85-102.

Mecklenburg, N. (2008). Interkulturalität und Komik bei Emine Sevgi Özdamar [Interculturality and Comedy in Emine Sevgi Özdamar's Work]. In Das Mädchen aus der Fremde. Germanistik als interkulturelle Literaturwissenschaft [The Girl from a Foreign Land. German Studies as Intercultural Literary Studies] (pp. 506-535). München: iudicium verlag. (In German).

Murti, K. P. (2012). To Veil or not to Veil. Europe’s Shape-Shifting 'Other'. Oxford: Lang.

Özdamar, E. S. (2006). Sonne auf halbem Weg. Die Istanbul-Berlin-Trilogie [Sun halfway. The Istanbul-Berlin Trilogy]. Köln: Kiepenheuer \& Witsch. (In German). 
Özdamar, E. S. (2011). Perikizi. Ein Traumspiel [Perikizi. A dream play]. In U. B. Carstensen \& S. Lieven (Eds.), Theater Theater - Odyssee Europa, Aktuelle Stücke 20/10 [Theatre Theatre-Odyssey Europe, Current Plays 20/10] (pp. 271-333). Frankfurt a. M.: Fischer. (In German).

Perrone Capano, L. (2007a). Leseprozesse und Analyse literarische Texte im Kontext Deutsch als Fremdsprache [Reading processes and analysis of literary texts in the context of German as a foreign language]. Aachen: Shaker. (In German).

Perrone Capano, L. (2007b). Sprachfremde" and "Fremderfahrung" as Acoustic and Visual Experience in Works by Yoko Tawada and Emine Sevgi Özdamar. In R. Schechtman \& S. Roberts (Eds.), Finding the Foreign (pp. 245-260). Newcastle: Cambridge Scholars Press.

Schlößler, F. (2010). Das Theaterevent Odyssee Europa der Kulturhauptstadt Essen. Prekäre Männlichkeit und Emine Sevgi Özdamars Traumspiel Perikizi [The theatre event Odyssey Europe of the Capital of Culture Essen. Precarious Masculinity and Emine Sevgi Özdamar's Dream Play Perikizi]. Zeitschrift für Interkulturelle Germanistik [Fournal for Intercultural German Studies], 1(2), 79-95. doi: 10.14361/zig.2010.0207. (In German).

Wagner, K. (2019). Geboren im Fluss des Erzählens. Pikareske Schreibweisen in Romanen von Irmgard Keun, Irmtraud Morgner und Emine Sevgi Özdamar [Born in the Flow of Narrative. Picaresque Writing in Novels by Irmgard Keun, Irmtraud Morgner and Emine Sevgi Özdamar]. Würzburg: Königshausen \& Neumann. (In German).

Weber, B. M. (2013). Violent authenticities: The work of Emine Sevgi Özdamar and Feridun Zaimoglu. In B. M. Weber (Ed.), Violence and gender in the "new" Europe: Islam in German Culture (pp. 173-198). New York: Palgrave Macmillan.

\section{Список литературы}

Allocca, D. (2016). BerlinoGrafie, letteratura nomade e spazi urbani: I percorsi di Emine Sevgi Özdamar e Terézia Mora [BerlinGraphies, nomadic literature and urban spaces: The paths of Emine Sevgi Özdamar and Terézia Mora]. Milano: LED. (In Italian).

Brunner, M. E. (2004). Migration ist eine Hinreise. Es gibt kein „Zuhause”, zu dem man zurück kann [Migration is a journey there. There is no 'home' to return to]. In M. Durzak (Ed.), Die andere deutsche Literatur [The other German literature] (pp. 71-90). Würzburg: Königshausen \& Neumann. (In German).

Budde, J. (2017). Nomadic Narrative: Interkulturelle Stadtnomadinnen. Inszenierungen weiblicher Flanerie- und Migrationserfahrung in der deutsch-türkischen und türkischen Gegenwartsliteratur am Beispiel von Aysel Özakin, Emine Sevgi Özdamar und Asli Erdogan. Studien zur deutsch-türkischen Literatur und Kultur [Nomadic Narrative: Intercultural Urban Nomads. Stagings of Female Flanerie and Migration Experiences in German-Turkish and Turkish Contemporary Literature Using the Example of Aysel Özakin, Emine Sevgi Özdamar and Asli Erdogan. Studies on German-Turkish Literature and Culture]. Würzburg: Königshausen \& Neumann. (In German). 
Carstensen, U. B., \& Lieven, S. v (Eds.). (2011). Theater Theater - Odyssee Europa. Aktuelle Stücke 20/10 [Theatre Theatre-Odyssey Europe. Current plays 20/10]. Frankfurt a. M.: Fischer. (In German).

Cavafy, C. P. (1992a). Ithaka. In E. Keeley \& P. Sherrard (Trans.), Collected Poems (Revised Edition, pp. 34-35; By C. P. Cavafy). Princeton University Press.

Cavafy, C. P. (1992b). Waiting for the Barbarians. In E. Keeley \& P. Sherrard (Trans.), Collected Poems (Revised Edition, pp. 18-19; By C. P. Cavafy). Princeton University Press.

Fischer, A. (2014). “Brecht hätte gerne eine Mitarbeiterin wie dich gehabt”. Zur Inszenierung von transkultureller Autorschaft und auktorialem Traditionsverhalten bei Emine Sevgi Özdamar ["Brecht would have liked to have had a collaborator like you". On the Staging of Transcultural Authorship and Authorial Traditional Behaviour in Emine Sevgi Özdamar.]. In S. Kyora (Ed.), Subjektform Autor: Autorschaftsinszenierungen als Praktiken der Subjektivierung [Subject form author: Stagings of authorship as practices of subjectification] (pp. 247-265). Bielefeld: Transcript. (In German).

Genz, J. (2016). Von der Polyglossie zur Polyphonie - transnationale Identitätsbildung bei Emine Sevgi Özdamar und Roger Manderscheid [From Polyglossia to Polyphony Transnational Identity Formation in the Works of Emine Sevgi Özdamar and Roger Manderscheid]. In N. Potysch \& M. Bauer (Eds.), Deutungsspielräume:

Mehrdeutigkeit als kulturelles Phänomen [Interpretive scope: Ambiguity as a cultural phenomenon] (pp. 91-114). Frankfurt a. M: Peter Lang. (In German).

Gezen, E. (2018). Brecht, Turkish theater, and Turkish-German literature: Reception, adaptation, and innovation after 1960. Rochester, New York: Camden House.

Gutjahr, O. (2016). Inszenierungen eines Rollen-Ich. Emine Sevgi Özdamars theatrales Erzählverfahren [Stagings of a Role-It. Emine Sevgi Özdamar's theatrical narrative process]. In Y. Dayioğlu-Yücel \& O. Gutjahr (Eds.), Text + Kritik. Heft 211: Emine Sevgi Özdamar [Text + Criticism. Issue 211: Emine Sevgi Özdamar] (pp. 8-18). München: Richard Boorberg Verlag. (In German).

Höfer, K. (2019). Gespielte Träume und Traumspiele. Traumdarstellungen in der Dramatik des 20. Und 21. Fahrhunderts [Played Dreams and Dream Games. Representations of Dreams in 20th and 21st Century Drama]. München: Fink. (In German).

Jonczyk, A. (2015). Die Identitätssuche im Emine Sevgi Özdamars Roman "Die Brücke vom Goldenen Horn" und im Theaterstück "Perikizi. Ein Traumspiel" [The search for identity in Emine Sevgi Özdamar's novel 'The Bridge of the Golden Horn' and in the play "Perikizi. A Dream Play]. In C. Gansel, M. Joch, \& M. Wolting (Eds.), Zwischen Erinnerung und Fremdheit: Entwicklungen in der deutschen und polnischen Literatur nach 1989 [Between Memory and Foreignness: Developments in German and Polish Literature after 1989] (pp. 117-132). Göttingen: V\&R Unipress. (In German).

Konuk, K. (2010). Taking on German and Turkish History: Emine Sevgi Özdamar's Seltsame Sterne. In A. Neuwirth (Ed.), Europa im Nahen Osten - der Nahe Osten in Europa [Europe in the Middle East-The Middle East in Europe] (pp. 221-242). Berlin: Akademie Verlag. (In German).

Mecklenburg, N. (2007). Karnevalistische Ästhetik des Widerstands. Formen des gesellschaftlich-komischen bei Emine Sevgi Özdamar. Peter-Weiss-Jahrbuch für Lit- 
eratur, Kunst und Politik im 20. Und 21. Peter-Weiss-fahrbuch für Literatur, Kunst und Politik im 20. und 21. Fahrhundert, 16, 85-102.

Mecklenburg, N. (2008). Interkulturalität und Komik bei Emine Sevgi Özdamar [Interculturality and Comedy in Emine Sevgi Özdamar's Work]. In Das Mädchen aus der Fremde. Germanistik als interkulturelle Literaturwissenschaft [The Girl from a Foreign Land. German Studies as Intercultural Literary Studies] (pp. 506-535). München: iudicium verlag. (In German).

Murti, K. P. (2012). To Veil or not to Veil. Europe's Shape-Shifting 'Other'. Oxford: Lang.

Özdamar, E. S. (2006). Sonne auf halbem Weg. Die Istanbul-Berlin-Trilogie [Sun halfway. The Istanbul-Berlin Trilogy]. Köln: Kiepenheuer \& Witsch. (In German).

Özdamar, E. S. (2011). Perikizi. Ein Traumspiel [Perikizi. A dream play]. In U. B. Carstensen \& S. Lieven (Eds.), Theater Theater - Odyssee Europa, Aktuelle Stücke 20/10 [Theatre Theatre-Odyssey Europe, Current Plays 20/10] (pp. 271-333). Frankfurt a. M.: Fischer. (In German).

Perrone Capano, L. (2007a). Leseprozesse und Analyse literarische Texte im Kontext Deutsch als Fremdsprache [Reading processes and analysis of literary texts in the context of German as a foreign language]. Aachen: Shaker. (In German).

Perrone Capano, L. (2007b). Sprachfremde" and "Fremderfahrung" as Acoustic and Visual Experience in Works by Yoko Tawada and Emine Sevgi Özdamar. In R. Schechtman \& S. Roberts (Eds.), Finding the Foreign (pp. 245-260). Newcastle: Cambridge Scholars Press.

Schlößler, F. (2010). Das Theaterevent Odyssee Europa der Kulturhauptstadt Essen. Prekäre Männlichkeit und Emine Sevgi Özdamars Traumspiel Perikizi [The theatre event Odyssey Europe of the Capital of Culture Essen. Precarious Masculinity and Emine Sevgi Özdamar's Dream Play Perikizi]. Zeitschrift für Interkulturelle Germanistik [fournal for Intercultural German Studies], 1(2), 79-95. doi: 10.14361/zig.2010.0207. (In German).

Wagner, K. (2019). Geboren im Fluss des Erzählens. Pikareske Schreibweisen in Romanen von Irmgard Keun, Irmtraud Morgner und Emine Sevgi Özdamar [Born in the Flow of Narrative. Picaresque Writing in Novels by Irmgard Keun, Irmtraud Morgner and Emine Sevgi Özdamar]. Würzburg: Königshausen \& Neumann. (In German).

Weber, B. M. (2013). Violent authenticities: The work of Emine Sevgi Özdamar and Feridun Zaimoglu. In B. M. Weber (Ed.), Violence and gender in the "new" Europe: Islam in German Culture (pp. 173-198). New York: Palgrave Macmillan. 